\title{
PROFESIONALISME PENGAWAS DALAM PENGEMBANGAN MUTU GURU MADRASAH
}

\author{
Fitriah Masrullah \\ fitriahmasrulah@gmail.com \\ Institut Agama Islam Negeri Jember \\ Ghufron \\ gufronsaja@gmail.com \\ Universitas Zainul Hasan Genggong Probolinggo \\ DOI: https://doi.org/10.35719/jieman.v2i1.6
}

\begin{abstract}
Abstrak
Pengawas madrasah merupakan sumberdaya yang seyogyanya memiliki keunggulan dan kapasitas di atas rata-rata guru lainnya. Pengawas dituntut untuk senantiasa memberikan bantuan dan layanan kepada personel guru serta membina dan mengembangkan madrasah yang efektif, efisien, dan bermutu, serta bermartabat. Penelitian ini merupakan kajian pustaka dengan menggunakan studi dokumenter dalam pengumpulan data, sedangkan analisis datanya menggunakan analisis isi. Hasil penelitian ini menunjukkan bahwa problematika kepengawasan dan pengembanagan mutu madrasah terletak pada kurangnya komitemen bersama untuk bisa menjadi lebih baik. Oleh karena itu, peningkatan mutu pendidikan memerlukan komitmen yang tinggi dari semua komponen yang menjadi penggerak madrasah tersebut. Tiap langkah dalam mewujudkan mutu pendidikan yang baik di madrasah memerlukan kedisiplinan, tanggung jawab, dan komitmen kolektif.
\end{abstract}

Kata kunci: madrasah, mutu guru, profesionalisme pengawas

\section{Abstract}

The madrasah supervisor is a resource that should have an advantage and a capacity above the average teacher. Supervisors are required to provide 
constant help and service to teacher personnel and to build and develop effective, efficient, and high-quality madrasah and dignity. The study was a library research using a documentary technique in data collection, while its data analysis used content analysis. The results of this study showed that management and stewardship lied in the lack of mutual commitment to improve. Therefore, improved education required high commitment from all the components that drive the madrasah. Each step in achieving a good education in the madrasah required discipline, responsibility, and a collective commitment.

Keywords: madrasah, school supervisor's professionalism, teacher quality

\section{Pendahuluan}

Pendidikan merupakan tanggung jawab pemerintah, orang tua, serta masyarakat. Jika tidak ditangani dengan baik, dikhawatirkan pedidikan kita ke depan akan semakin tidak jelas arahnya. Oleh karena itu, perlu perhatian yang sangat serius dari pemerintah, orang tua dan masyarakat. Di sisi lain kemajuan sebuah pendidikan diperlukan sebuah tata kelola yang bagus, karena ketika sebuah lembaga pendidikan dapat dipimpin oleh orang kompeten, maka akan tercipta sebuah pendidikan yang berkualitas.

Mutu pendidikan anatara lain ditentukan oleh pengawas yang profesional, kepala madrasah yang profesional, juga guru yang profesional. Namun, fakta di lapangan, supervisi pendidikan yang dilakukan oleh para pengawas masih perlu dibenahi. Cukup banyak pengawas menjalankan tugasnya belum maksimal dalam pelayanan dan bimbingan kepada guru madrasah karena keahlian dan keterampilannya yang kurang baik. Hal inilah yang sering dikeluhkan oleh para dewan guru. Idealnya seorang pengawas harus profesional dan mampu dari dalam hal pembinaan, bimbingan, pemberdayaan.

\section{Pembahasan}

\section{Konteks Pengawas dalam Implementasi Kebijakan}

Pengawas madrasah merupakan tugas fungsional yang tidak dapat dipandang sebelah mata. Pengawas bukan merupakan sebuah tugas yang diberikan kepada orang-orang atau guru-guru yang akan memasuki usia purna bakti, juga bukan pula sebagai sebuah tugas bagi kepala madrasah atau guru-guru yang tak ada akar rotan pun jadi. 
Pengawas mempunyai peran yang penting dalam proses peningkatan mutu pendidikan pada setiap satuan pendidikan. Pada waktu lalu mutu pendidikan selalu dihubungkan dengan guru dan peserta didik, sehingga pengawas hanyalah sebagai pelengkap saja. Fenomena ini bukanlah sebuah isapan jempol belaka, tapi setidaktidaknya masih terlihat eksistensinya sampai dengan saat ini.

Di masa silam, persepsi masyarakat khusus kalangan pendidikan, guru, staf dan warga madrasah yang lain tentang pengawasan madrasah boleh jadi hanya berkutat pada kunjungan pengawas ke madrasah, ke kelas-kelas guna melakukan penilaian tentang kesesuaian strategi pembelajaran oleh guru. Padahal jika kita menilik beberapa regulasi di atas, tugas, fungsi dan wewenang pengawas sangatlah luas.

Pengawas sebagai bagian penting dari madrasah yang memiliki pekerjaan serius untuk mengembangan Madrasah, yakni membentuk lingkungan madrasah yang kondusif untuk mewujudkan visi-nya sebagai proses "character building". Sebab pendidikan itu hakikatnya adalah proses menjadikan siswa menjadi manusia yang beriman, bertakwan kepada Allah, beakhlak mulia, serta karakter dan skill positif lainnya.

\section{Budaya Mutu Madrasah}

Dalam khazanah pendidikan nasional, madrasah telah mengalami perkembangan yang cukup pesat sejak awal abad ke dua puluh samapai sekarang. Secara historis madrasah adalah lembaga pendidikan yang dikembangkan untuk membantu keluarga dan masyarakat dalam memenuhi kebutuhan pendidikan.

Keluarga dan masyarakat sangat menaruh harapan kepada madrasah agar generasi mudanya mempunyai keterampilan untuk menghadapi kehidupan masa depan yang tidak menentu. Generasi muda diharapkan dapat menggapai keberhasilan, baik dalam kehidupan di dunia maupun di akhirat kelak. Ini sesuai dengan sabda Nabi Muhammad SAW.:

"Barang siapa yang ingin sukses di dunia maka hanya dapat dicapai dengan ilmu, barang siapa yang ingin berhasil diakhirat maka hanya dapat dicapai dengan ilmu, dan barang siapa yang berhasil di dunia dan akhirat maka hanya dapat dicapai dengan ilmu."

Istilah sekolah digunakan untuk menyebut kelembagaan pendidikan dasar dan menengah di bawah naungan Kementerian 
Pendidikan Nasional, sedangkan madrasah adalah untuk lembaga pendidikan tingat dasar dan menengah di bawah naungan Kementerian Agama. Di dalam madrasah terdapat mata pelajaran pendidikan agama Islam, yaitu: Aqidah Akhlak, Qur'an Hadits, Fiqih, Kedayaan Islam, serta ditambah Bahasa Arab. Dengan demikian, tamatan madrasah diharapkan memiliki kemampuan di bidang ilmu pengetahuan dan teknologi yang dilandasi dengan iman dan takwa. ${ }^{\circ}$

Dalam rangka untuk meningkatkan mutu madrasah baik secara kualitatif dan kuantitatif, perlu dilakukan strategi untuk meningkatkan mutu tersebut. Hal ini membutuhkan kerjasama dan keterlibatan semua pihak yang berkepentingan dengan madrasah.

Menurut Akmal Hawi, berikut strategi peningkatan mutu madrasah yang dapat dilakukan dengan usaha sebagai berikut: ${ }^{2}$

1. Akuntabilitas Proses

Untuk meningkatkan mutu madrasah, upaya yang paling efektif adalah dengan cara peningkatan akuntabilitas proses pendidikannya. Akuntabilitas proses diharapkan benar-benar mampu menjamin madrasah yang dapat menjaga dan meningkatkan mutunya secara progresif dan terus menerus. Mutu di sini tidak hanya menyangkut masalah isi saja, melainkan juga kesesuaian metodologi pembelajaran.

Akuntabilitas proses pendidikan dikembangkan dengan cara:

a. Lebih pada kegiatan belajar daripada mengajar.

b. Orientasi pelatihan guru lebih kepada memfasilitasi proses belajar daripada mengajar.

c. Menerapkan pengembangan kurikulum secara komprehensif yang dirancang untuk memelihara integritas pengembangan kemampuan akademik dan teknis dalam proses pembelajaran.

d. Mengembangkan sistem penilaian menyeluruh terhadap peserta didik untuk menentukan keberhasilan pendidikan sesuai tuntunan masyarakat.

e. Menerapkan manajemen sistem pendidikan dan pelatihan yang efektif dan efesien dengan memanfaatkan hasil pengalaman belajar awal, sehingga dapat diketahui peng-

\footnotetext{
${ }^{1}$ Abudin Nata, Manajemen Pendidikan: Mengatasi Kelemahan Pendidikan Islam di Indonesia, (Jakarta, Penada Media, 2003), 39.

${ }^{2}$ Akmal Hawi, Kapita Selekta Pendidikan Islam. (Palembang: IAIN Raden Fatah Press, 2008), 50.
} 
alaman belajar mana yang sudah dimiliki dan belum dikuasai.

f. Mengembangkan manajemen berbasis pada masyarakat madrasah, sehingga program dan proses pendidikan yang berlangsung dapat diterima dan didukung masyarakat.

Pendapat Akmal Hawi ini menjelaskan bahwa pengelola madrasah harus bertanggung jawab dalam hal pelaksanaan proses pembelajaran di madrasah. ${ }^{3}$ Madrasah harus meningkatkan mutu proses pembelajaran dengan melakukan tindakan seperti guru harus mengajak siswa aktif dalam proses pembelajaran bukan pengajaran (identik dengan guru sebagai pusat); guru berperan sebagai fasilitator (mengetahui apa yang dikehendaki oleh anak didik); guru menitik-beratkan dalam hal kognitif, afektif, dan psikomotorik begitu juga dalam hal penilaian; sebelum mengajar guru harus melakukan post test; dan mendidik anak didik sesuai dengan kebutuhan masyarakat.

2. Profesionalisme

Profesionalisme merupakan aspek penting lainnya untuk menentukan kualitas pendidikan. Selama ini di madrasah belum sepenuhnya menempatkan para profesional secara memadai untuk menunjang kegiatannya. Pertama, guru sebagai penanggungjawab utama perlu mendapatkan perhatian yang sungguh-sungguh. Ini didasari bahwa penentu keberhasilan pelaksanaan pendidikan di madrasah lebih banyak bertumpu pada manajemen guru, sehingga berbagai aspek yang berkaitan dengan guru perlu diperhitungkan, di antaranya, aspek rekrutmen, pelatihan perkembangan karir, dan isentif. Kedua, kepala madrasah sebagai personil yang memiliki posisi sangat strategis dalam meningkatkan mutu pendidikan. ${ }^{4}$

Oleh karena itu, penunjukkan kepala madrasah harus melalui seleksi ketat. Apabila memungkinkan dapat dibentuk dewan madrasah yang bertugas di antaranya mengadakan pemilihan kepala madrasah. Setelah melalui proses demokratis, kemudian diusulkan kepada pihak Kementerian Agama untuk mengeluarkan Surat Keputusannya.

Menurut Arifin, guru yang profesional akan tercermin dalam pelaksanaan pengabdian tugas-tugas yang ditindai dengan keahlian

\footnotetext{
${ }^{3}$ Akmal Hawi, Kapita Selekta Pendidikan Islam, 59

${ }^{4}$ Soebagio Atmodiwiro, Manajeman Pendidikan Indonesia, (Jakarta, Ardadidzya Jaya, 2002) 33
} 
baik dalam materi maupun metode. Selain itu, juga ditunjukkan melalui tanggung jawabnya dalam melaksanakan seluruh pengabdiannya. ${ }^{5}$

Dalam lembaga pendidikan Islam, istilah "guru salah kamar" merupakan istilah yang sering didengar, seperti guru Matematika mengajar PAI, guru PAI mengajar Olahraga, dan lain sebagainya. Lembaga pendidikan Islam dituntut untuk merekrut guru yang sesuai dengan sertifikat pendidiknya, berpengalaman, dan diberi gaji tambahan untuk kesejahteraan guru. Selanjutnya, pemilihan kepala madrasah harus diserahkan kepada komite madrasahnya bukan kepada Kementerian Agama. Biasanya kepala madrasah yang dipilih oleh kemenag lebih kepada nepotisme, dapat diintervensi, terjadinya korupsi berjemaah, dan masalah-masalah lainnya.

3. Meningkatkan Anggaran Biaya

Berkenaan dengan pembiayaan madrasah, maka perlu upaya sistematis dan terprogram untuk memperjuangkan anggaran pendidikan lebih besar dan keadaan sekarang, sehingga pos-pos pengeluaran untuk kepentingan peningkatan mutu madrasah dapat terpenuhi secara baik, seperti pengadaan sarana dan prasarana. Pihak Kementerian Agama harus melakukan upaya serius untuk mendapatkan anggaran biaya pendidikan yang lebih besar untuk madrasah. Upaya ini memiliki arti penting meningkatkan mutu dan citra madrasah. Di sisi status madrasah disamakan dengan kedudukannya dengan sekolah di bawah naungan Kementerian Pendidikan dan Kebudayaan, namun dari sisi finansial ada ketidakadilan yang terjadi. Dualisme perlakuan selama ini harus segera disadari dan dilakukan upaya nyata dalam rangka peningkatan mutu madrasah

Untuk menciptakan anak yang berakhlak mulia, lembaga pendidikan Islam memerlukan biaya sebagai suatu usaha untuk mencapai tujuan pendidikan nasional. Untuk itu pihak Kementerian Agama harus mengetahui hal tersebut dengan melakukan lobi kepada pemerintah atau kepada pihak swasta untuk mendapatkan biaya yang besar seperti halnya yang diterima oleh Kementerian Pendidikan dan Kebudayaan. Lembaga pendidikan Islam selalu mendapatkan diskriminasi (dalam hal biaya) dari pemerintah.

\footnotetext{
${ }^{5}$ Muzayyin Arifin. Kapita Selekta Pendidikan Islam.(Jakarta. Bumi Aksara, 2009) 55
} 
Menurut Amin, negara dan agama merupakan suatu hal yang tidak terpisahkan. ${ }^{6}$ Selanjutnya, agama memiliki peran yang amat besar dalam hal memajukan suatu negara seperti halnya pendidikan. Untuk itu, tidak ada alasan bagi pemerintah tidak membantu keperluan agama (termasuk pendidikan yang dikembangkan oleh ormas Islam) mengingat perannya yang amat besar.

4. Meningkatkan Partisipasi Masyarakat

Menyadari akan pentingnya partisipasi masyarakat dalam peningkatan mutu madrasah harus dimaknai secara luas, yang tidak hanya memberikan kontribusi secara finansial bagi kepentingan madrasah seperti yang dilakukan Komite Madrasah selama ini, namun juga sama pentingnya yaitu keterlibatan masyarakat dalam memerankan dirinya sebagai pengendali kualitas madrasah.

Eksistensi Komite Madrasah selama ini harus segera diluruskan kembali. Jangan sampai komite madrasah hanya untuk kepentingan kegiatan pengumpulan dana madrasah saja, melainkan untuk benar-benar dapat meningkatkan peranserta masyarakat memajukan pendidikan.

Melalui Komite Madrasah, orang tua dan masyarakat dapat berpartisipasi dalam pembuatan keputusan madrasah. Dengan demikian masyarakat dapat memahami, mengawasi, dan membantu madrasah dalam pengelolaan termasuk dalam kegiatan belajar. Besarnya peranan masyarakat dalam pengelolaan madrasah tersebut mungkin dapat menimbulkan benturan kepentingan antara madrasah dengan masyarakat. Untuk mencegah terjadinya benturan kepentingan antara madrasah, orang tua dan masyarakat, maka perlu dirumuskan batasan peranan masing-masing.

Menurut Akmal Hawi, peranserta masyarakat jangan hanya terletak pada segi finansial (biaya). ${ }^{7}$ Madrasah membutuhkan peran serta masyarakat bukan hanya dibidang finansial, melainkan peran dalam hal pengawasan, pemikiran dan moral. Pengawasan dalam artian mengawasi penyelenggaraan proses pembelajaran, biaya operasional madrasah, kebijakan madrasah. Pemikiran dalam artian memberikan kontribusi pemikiran berupa ide dan gagasan. Dan moral dalam artian memberikan semangat, motivasi, menyontohkan akhlak yang baik kepada anak didik.

\footnotetext{
${ }^{6}$ Samsul Munir Amin, Sejarah Peradaban Islam,( Jakarta: Amzah, 2010), 31.

${ }^{7}$ Akmal Hawi, Kapita Selekta Pendidikan Islam, 59
} 


\section{Evaluasi Diri}

Penggunaan istilah evaluasi untuk madrasah-madrasah khususnya madrasah masih belum populer, padahal evaluasi diri ini merupakan keadaan dimana kita dapat melihat tingkat keberhasilan proses pendidikan yang berlangsung serta kelemahannya sehingga dapat segera diperbaiki.

Proses evaluasi dan berkaitan erat dengan analisa terhadap data yang dikumpulkan berkaitan dengan komponen: ${ }^{8}$

a. Efesiensi, yakni keterkaitan antara masukan/sumber daya dan proses, dan menunjukkan derajat kehematan dalam pengunaan sumber daya dalam proses.

b. Produktivitas, yakni keterkaitan antara proses dan keluaran (dalam hal ini), menunjukkan jumlah satuan hasil yang terjadi karena suatu proses tertentu, dihitung berdasarkan penggunaan sumber daya tertentu.

c. Efektivitas, yakni keterkaitan antara tujuan dan hasil yang dinyatakan, dan menunjukkan derajat kesesuaian antara tujuan yang dinyatakan dengan hasil yang dicapai.

d. Akuntabilitas, yakni derajat pertanggunngjawaban dalam penyelenggaraan madrasah.

e. Inovasi, yakni berhubungan derajat kelenturan madrasah atau program-program terhadap perubahan yang terjadi di masyarakat.

Menurut Anas Sudjiono bahwa evaluasi pendidikan memiliki fungsi sebagai berikut: mengukur kemajuan, menunjang penyusunan rencana, memperbaiki atau melakukan penyempurnaan kembali. ${ }^{9}$ Evaluasi merupakan tahap akhir dari kesemuan komponen di atas. Evaluasi digunakan untuk menilai seberapa jauh keberhasilan dalam proses pembelajaran dan untuk perbaikan. Evaluasi merupakan hal yang penting karena dengan evaluasi kita dapat mengetahui keberhasilan yang dicapai dan mana komponenkomponen yang akan diperbaiki untuk selanjutnya.

Mengenai peningkatan mutu madrasah dalam suatu situs menjelaskan bahwa upaya meningkatkan mutu pendidikan sudah sejak lama dilakukan pemerintah. Beberapa aspek yang menjadi sasaran dalam upaya tersebut adalah meningkatkan kemampuan

${ }^{8}$ Syaiful Sagala, Kemampuan Profesionalisme Guru dan tenaga Kependidikan Cet. III (Bandung: Penerbit Alfabeta, 2011)

${ }^{9}$ Anas Sudjiono Evaluasi Pendidikan (Jakarta. Raja Grafindo Persada, 2011) 55 
guru sehubungan dengan mutu proses belajar mengajar; meningkatkan kemampuan kepala madrasah sehubungan dengan pengelolaan dan manajemen madrasah; dan meningkatkan kemampuan para pengawas sehubungan dengan proses pengawasan dan penilaian pelaksanaan pendidikan di madrasah.

\section{Peran Pengawas dalam Peningkatan Mutu Madrasah}

Mutu pendidikan dalam konteks tulisan ini adalah mutu proses pembelajaran dan hasil belajar. Mutu proses mengacu kepada standar proses seperti yang tertuang di dalam PP Nomor 19 tahun 2005 tentang Standar Nasional Pendidikan, dengan semua perubahannya. Pada Bab 1 Pasal 1 ayat (6) dinyatakan: "Standar proses adalah standar naisonal pendidikan yang berkaitan dengan pelaksanaan pembelajaran pada satu satuan pendidikan untuk mencapai standar kompetensi lulusan." Standar kompetensi lulusan ditegaskan pada ayat (4) merupakan kualifikasi kemampuan lulusan yang mencakup sikap, pengetahuan, dan keterampilan."

Pada pasal 19 ayat (1) Peraturan Pemerintah ini dinyatakan, "Peroses pembelajaran pada satuan pendidikan diselenggarakan secara interaktif, inspiratif, menyenangkan, menantang, memotivasi perserta didik untuk berpartisipasi aktif, serta memberikan ruang yang cukup bagi prakarsa, kretivitas, dan kemandirian sesuai dengan bakat, minat, dan perkembangan fisik serta psikologis perserta didik." Pada ayat (2) ditambahkan, "Selain ketentuan sebagaimana yang dimaksud pada ayat (1), dalam proses pembelajaran pendidik memberikan keteladanan." Pada ayat (3) ditambahkan lagi, "Setiap satuan pendidikan melakukan perencanaan proses pembelajaran, pelaksanaan proses pembelajaran, penilaian proses pembelajaran, dan pengawasan proses pembela-jaran untuk terlaksananya proses pembelajaran yang efektif dan efisien."

Jadi, mutu pendidikan dalam konteks makalah ini adalah mutu proses yang mengacu kepada standar proses dan mutu hasil yang mengacu kepada standar komepetnsi lulusan. Mutu proses memiliki hubungan kausal dengan mutu hasil. Jika proses pembelajaran bermutu, tentulah standar komptensi lulusan dapat dicapai dengan bermutu pula.

Pencapaian kedua mutu yang dimaksud sudah jelas membutuhkan keberadaan pengawas madrasah. Hal itu terkait dengan tugas pokoknya yakni menilai dan membina teknik pendidikan dan treknik administrasi. Penilaian mengacu kepada 
pengumpulan, pengolahan, dan penafsiran data dari subjek yang dinilai (proses pembelajaran), sedangkan pembinaan mengacu kepada hasil penilaian. Dengan demikian, keberadaan pengawas madrasah untuk meningkatkan mutu sangatlah penting

\section{Realitas Pengawas Madrasah; Perkuat Fungsi dan Komitmen}

Dalam Ketentuan perundang-undangan terutama Peraturan Menteri Pendayagunaan Aparatur Negara dan Reformasi Birokrasi Nomor 21 tahun 2010 disebutkan bahwa pengawas satuan pendidikan pada jalur madrasah adalah tenaga kependidikan profesional berstatus Pegawai Negeri Sipil (baca: Aparatur Sipil Negara) yang diangkat dan diberi tugas serta wewenang secara penuh oleh pejabat berwenang untuk melakukan pembinaan dan pengawasan pendidikan baik pengawasan akademik maupun pengawasan manajerial pada satuan pendidikan yang ditunjuk.

Peraturan Menteri Pendidikan Nasional Nomor 12 Tahun 2007 tentang Standar Pengawas Madrasah/Madrasah dan Peraturan Menteri Agama Nomor 31 tahun 2013 tentang Pengawas Madrasah dan Pengawas Pendidikan Agama Islam pada Sekolah menegaskan bahwa seorang pengawas harus memiliki enam kompetensi minimal, yaitu: kompetensi kepribadian, sepervisi manajerial, sepervisi akademik, evaluasi pendidikan, penelitian dan pengembangan, serta kompetensi sosial. Pengawasan manajerial sasarannya adalah kepala madrasah dan staf madrasah lainnya, sedangkan sasaran supervisi akademik sasarannya adalah guru. ${ }^{10}$

Jika dilihat dari realitas kondisi madrasah dan SDM yang dimiliki oleh mayoritas madrasah di lingkungan kantor wilayah kementerian agama saat ini masih sangat membutuhkan kehadiran dan keterlibatan pengawas madrasah. Diakui atau tidak, kualitas madrasah baik dari sisi akademik maupun manajerial, mayoritas masih rendah. Dalam konteks ini peran pengawas madrasah sangat strategis dan menentukan. Untuk itu para pengawas madrasah ditantang untuk benar-benar memiliki kompetensi dan bekerja sesuai dengan tuntutan profesionalitasnya sehingga kehadirannya menjadi damabaan dan harapan madrasah binaannya.

Beberapa hal yang masih menjadi sorotan tajam dari guru dan kepala madrasah terhadap eksistensi pengawas, antara lain:

${ }^{10}$ Dadang Suhardan, Supervisi Proesional dan Layanan dalam Meningkatkan mutu Pembelajaran Pembelajaran di Era Otonomi Cet. III; (Bandung:Alfabeta, 2010) 
pertama, pengawas kurang melakukan kunjungan. Kedua, pengawas madrasah kurang apresiatif terhadap guru dan kepala madrasah. Ketiga, minimnya kemampuan teknik edukatif dibandingkan guru dan kepala madrasah. Keempat, pengawas kurang memiliki kemampuan berbasis pendidikan. Dengan kata lain, dari enam kompetensi yang harus dimiliki pengawas sesuai tuntutan Permendiknas 12/2007, kompetensi supervisi akademis dan manajerial, penelitian dan pengembangan serta evaluasi pendidikan masih jauh dari harapan ideal. Kondisi seperti di atas diperparah dengan latar belakang pendidikan pengawas yang tidak semua memenuhi standar kualifikasi yang disyaratkan. Belum semua pengawas madrasah mengikuti diklat kepengawasan, serta sistem pelayanan dan bimbingan terhadap pengawas belum melibatkan tim ahli/pakar.

Pengawas madrasah diharapkan turut berkontribusi pada kemajuan pendidikan nasional secara signifikan. Ia mempunyai posisi yang strategis untuk membina para pendidik dan kepala madrasah agar lebih profesional dan meningkatkan kinerja madrasah di wilayah kerjanya. Dalam kenyataan, entah karena sistem rekrutmen maupun kinerjanya, pengawas madrasah masih seringkali ditempatkan tidak pada posisinya sebagai pembina melainkan sebagai jabatan formalitas yang minim kualitas. Hal ini disebabkan oleh pandangan bahwa pengawas madrasah adalah orang yang kurang sukses menapaki karier. Pengawas semacam tenaga buangan dari guru atau kepala madrasah atau tenaga struktural yang memperpanjang masa kerjanya.

Dengan demikian, ia diberi posisi yang "khas", menjadi pengawas madrasah. Hal negatif lain bisa juga disebabkan oleh kurangnya pembinaan dari dinas pendidikan dalam memberikan wewenang kepada pengawas. Namun, kondisi pengawas yang masih dipandang sebelah mata tersebut bukanlah murni disebabkan oleh diri pengawas, tetapi juga karena sistem yang ada. Dengan kata lain, pandangan negatif terhadap pengawas tersebut juga bisa disebabkan oleh model kepemimpinan dan sistem manajemen yang ada.

Peran pengawas madrasah sebagai penjamin mutu pendidikan di madrasah binaanya dinilai sangat stategis. Pengawas madrasah semestinya dijadikan mitra strategis dalam mengendalikan mutu pendidikan di madrasah, mengawal pelaksanaan delapan standar nasional pendidikan terutama di dalamnya mengawal kinerja guru dan kepala madrasah. 


\section{Simpulan}

Peningkatan mutu pendidikan tidak bisa dilepaskan dengan penerapan standar dalam penyelenggaraan pendidikan. Setiap penyelenggara pendidikan berkewajiban untuk menerapkan dan mencapai standar itu agar memenuhi standar mutu minimal sebagai modal dasar untuk meningkatkan mutu pendidikan. Upaya meningkatkan mutu pendidikan memerlukan perencanaan dan proses yang panjang. Peningkatkan mutu pendidikan membutuhkan rancangan tentang apa yang hendak ditingkatkan, memilih bagian yang perlu ditingkatkan, dan menghasilkan output yang paling unggul di antara madrasah-madrasah yang ada. Oleh karena itu, peningkatan mutu pendidikan memerlukan komitmen yang tinggi dari semua komponen yang menjadi penggerak madrasah tersebut. Tiap langkah dalam mewujudkan mutu pendidikan yang baik di madrasah memerlukan disiplin, tanggung jawab dan komitmen bersama.

\section{Daftar Pustaka}

Amin, Samsul Munir. Sejarah Peradaban Islam. Jakarta: Amzah, 2010.

Arifin, Muzayyin. Kapita Selekta Pendidikan Islam. Jakarta: Bumi Aksara, 2009.

Atmodiwiro, Soebagio. Manajeman Pendidikan Indonesia. Jakarta: Ardadidzya Jaya, 2002.

Hawi, Akmal. Kapita Selekta Pendidikan Islam. Palembang: IAIN Raden Fatah Press, 2008.

Nata, Abudin. Manajemen Pendidikan: Mengatasi Kelemahan Pendidikan Islam di Indonesia. Jakarta: Penada Media, 2003.

Qomar, Mujamil. Pesantren: Dari Transformasi Metodologi Menuju Demokratisasi Institusi. Jakarta: Erlangga, 1996.

Sagala, Syaiful. Kemampuan Profesionalisme Guru dan tenaga Kependidikan. Cet. III. Bandung: Alfabeta, 2011.

Sudjiono, Anas. Evaluasi Pendidikan. Jakarta: Raja Grafindo Persada, 2011.

Suhardan, Dadang. Supervisi Proesional dan Layanan dalam Meningkatkan Mutu Pembelajaran Pembelajaran di Era Otonomi. Cet. III. Bandung: Alfabeta, 2010. 